Sedyawati, Edi. 2002. Penelitian Kualitatif Sosial-Keagamaan pada Pelatihan Metodologi Penelitian Bidang Sosial Keagamaan. Jakarta: DPPM Ditjen DIKTI.

Siti Partini. 1999. Profil Lansia di DIY. Laporan Penelitian. Yogyakarta: Lemlit UNY bekerja sama dengan BKKBN dan UNFPA.

Sutarno. 1982. Kesejahteraan Sosial, Pelayanan Sosial dan Kebijakan Sosial. Bandung: STKS.

Swasono, Meutia, Farida. 1995. Peranan dan Kontribusi Usia Lanjut. Laporan Penelitian. Jakarta: FISIP UI.

Tilaar, H.A.R. 1998. Beberapa Agenda Reformasi Pendidikan Nasional dalam Perspektif Abad 21. Magelang: Tera Indonesia.

\section{DUKUNGAN SOSIAL DAN STRATEGI COPING}

PARA LANSIA

Oleh:

Siti Rohmah Nurhayati

\section{Universitas Negeri Yogyakarta}

\section{Abstract}

The aims of this study were to identify the problems in the elderly, prove the relationship between social-support and coping strategies in the elderly describe the social support received by the elderly, and describe the patterns of coping strategies in the elderly related with social support received by the elderly. The primary data source was a quantitative survey with 30 elderly in the Posyandu Lansia Ketonggo Wonokromo Pleret Bantul. Data were collected by questioner and analyzed by regression and descriptive analysis. Results indicated that the problems experienced by the majority of elderly in this study were a disorder of the muscles, instability of the body decreasing in the sensory function, cataracts or instability of the bodry decreasing in the sensory finction, cataracts or mearsightedness, bodedness, lack of fin sense difficulties in managing boten, as weil as using the telephone. A significant positive correlation between social support and problem focused coping and a significant negative correlation between social support and emotion focused coping were confirmed. Social support was high enough on the subject, particularly the family support and support from significant other. The pattern of use of problem focused coping can be predicted from general social support and particularly from the support of friends, while the use of emotion focused coping can be predicted from social support in general and particularly from significant other support.

Keyword: social support, patterns of coping strategies

\section{PENDAHULUAN}

Usia lanjut adalah suatu fase yang pasti akan dialami oleh semua orang yang dikaruniai usia panjang, yang mana terjadinya tidak bisa dihindari oleh siapapun. Proses penuaan yang terjadi pada lansia tentunya berdampak pada berbagai aspek kehidupan, baik sosial, ekonomi, maupun kesehatan, karena dengan semakin 
bertambahnya usia, fungsi organ tubuh akan semakin menurun sehingga dapat berakibat buruk pada kesehatan.

Lansia juga rentan terhadap permasalahan psikologis maupun sosial karena seiring dengan penuaan yang terjadi, lansia akan menghadapi peningkatan perubahan kehidupan yang penuh tekanan seperti kehilangan pasangan, pensiun, atau pemindahan tempat tinggal secara paksa (Bisconti \& Bergeman, 1999). Stressor tambahan bagi lansia di antaranya adalah menurunnya pendapatan, kehilangan ijin mengemudi, sakit, atau menjadi perawat bagi anggota keluarga yang sakit (Schultz\&Heckhausen, 1996). Bagi kebanyakan lansia, stressor-stressor tadi terus meningkat sehingga berakumulasi menyebabkan frustrasi sementara mereka masih memiliki keinginan untuk menjaga gaya hidup yang normal serta kemandirian dari orang lain. Menurut Vezina \& Giroux (1988), stressor bagi lansia seringkali merupakan kesulitan sehari-hari seperti kekhawatiran terhadap kesehatan dan kesejahteraan, tidak memiliki uang untuk mencukupi kebutuhan pokok sehari-hari, kesepian, serta bermasalah dengan cucu.

Selain kesulitan sehari-hari seperti disebutkan di atas, lansia juga dapat mengalami ketidakmampuan fungsional, yaitu ketidak-mampuan untuk mandiri dan beraktivitas dalam hidup sehari-hari. Beberapa orang menemukan diri mereka tidak lagi mampu melakukan kegiatan sehari-hari yang dulu dapat mereka lakukan, seperti mandi, berjalan dari satu tempat ke tempat yang lain, atau naik kendaraan umum sendiri. Hal tersebut masih ditambah dengan masalah seperti penurunan penglihatan dan pendengaran, sehingga rentan terhadap kecelakaan.

Mencermati berbagai permasalahan yang dihadapi oleh lansia di atas, maka salah satu aspek dari penuaan adalah kesuksesan dalam melakukan coping atas berbagai permasalahan yang dihadapinya.Coping adalah usaha untuk menghadap tekanan, juga usaha untuk mengatasi kondisi yang menyakitkan atau mengancam (Lazarus, dalam Pestonjee, 1992). Coping juga merupakan kecenderungan bentuk tingkah laku individu untuk melindungi diri dari tekanan-tekanan psikologis yang ditimbulkan oleh problematika sosial (Pearlin dan Scholeer, 1978).

Lazarus dan Folkman (1984) membedakan strategi coping menjadi dua macam. Pertama, disebut dengan problem focused coping (PFC), merupakan usaha individu untuk mengurangi atau menghilangkan stress yang dirasakannya dengan cara menghadapi masalah yang menjadi penyebab timbulnya stress secara langsung. Usaha yang dilakukan oleh individu lebih banyak diarahkan kepada bentuk-bentuk usaha untuk menyelesaikan masalah yang dihadapi. Kedua, disebut dengan emotion focused coping (EFC), merupakan usaha yang dilakukan oleh individu untuk mengurangi atau menghilangkan stress yang dirasakannya tidak dengan menghadapi masalahnya secara langsung, tetapi lebih diarahkan untuk menghadapi tekanan-tekanan emosi dan untuk mempertahankan keseimbangan afeksinya.

Penelitian tentang strategi coping pada umumnya menemukan bahwa PFC berhubungan dengan penyesuaian yang lebih baik dan EFC berkaitan dengan penyesuaian yang lebih buruk (Aldwin dalam Park, dkk, 2001) serta distress dan gangguan (Stanton, dkk, 1994). Secara khusus, Causey \& Dubow (dalam Lengua \& Stormshak (2000) menemukan bahwa strategi coping seperti pemecahan masalah dan pengambilan keputusan berhubungan dengan tingkat simptom yang lebih rendah, sedangkan strategi avoidant berkaitan dengan tingkat simptom yang lebih tinggi.

Terdapat beberapa faktor yang berpengaruh terhadap pemilihan strategi coping. Salah satu faktor yang dipercaya mempengaruhi pemilihan strategi coping adalah dukungan sosial (Watson, dkk, 1984; Taylor, 1995; Dalton, dkk, 2001). Dukungan sosial menurut Gottlieb (1983) adalah informasi atau nasehat verbal, bantuan nyata, atau tindakan yang diberikan oleh keakraban sosial yang bermanfaat secara emosional dan memiliki efek perilaku tertentu bagi penerima. Sarafino (1998) menjelaskan bahwa dukungan sosial mengacu pada kesenangan yang 
dirasakan, perhatian, penghargaan atau bantuan yang diperoleh seseorang dari orang lain atau kelompok.

Dukungan sosial merupakan sumber pengatasan yang mempengaruhi sejak proses penilaian terhadap ancaman sampai pada usaha mengatasi masalah (Watson, 1984). Beberapa penelitian (dalam Watson, dkk, 1984) menunjukkan bahwa dukungan sosial dari orang lain merupakan keuntungan bagi orang yang sedang tertekan. Schrabacq (1996) mengemukakan bahwa persepsi seseorang akan adanya dukungan sosial bagi dirinya dapat meningkatkan perasaan kontrol diri, kemananan, dan kesesuaian. Perasaan ini dapat menjadi dasar emosi untuk melakukan aktifitas yang lebih menantang, yang mengarah pada perkembangan keterampilan dan pengetahuan yang lebih tinggi. Secara umum dukungan sosial dapat diperoleh misalnya dar keluarga, teman, sahabat, tetangga atau konselor. Dukungan sosia tersebut dapat berbentuk materi, informasi, penilaian, bimbingan, maupun dukungan emosional.

Berdasarkan uraian di atas tentang berbagai masalah yang mungkin dialami lansia serta strategi coping yang dapat dilakukan serta perlunya dukungan sosial bagi suksesnya strategi coping seseorang, maka penulis bermaksud meneliti keterkaitan antara dukungan sosial dengan strategi coping yang digunakan dalam menghadapi masalah pada lansia.

Tujuan penelitian ini adalah untuk: 1) membuktikan hubungan antara dukungan sosial dengan strategi coping pada para lansia; 2) menguraikan dukungan sosial yang diterima para lansia; 4) menerangkan polastrategi coping pada para lansia berkaitan dengan dukungan sosial yang diterimanya.

\section{Metode}

Subjek dalam penelitian ini adalah para lansia anggota posyandu lansia dusun Ketonggo Wonokromo Pleret, Bantul. Subjek terdiri dari 20 orang lansia perempuan dan 10 orang lansia laki-laki. Variabel penelitian ini adalah dukungan sosial sebagai variabel independen dan problem focused coping serta emotion focused coping sebagai variabel dependen.

Dukungan sosial diukur dengan menggunakan skala dukungan sosial yang terdiri dari 3 sumber dukungan, yaitu dukungan keluarga, dukungan teman, serta dukungan dari significant others. Makin tinggi skor yang diperoleh subjek berarti makin tinggi dukungan sosial yang diperoleh subjek dalam menghadapi masalahnya. Reliabilitas dari skala dukungan sosial ini adalah 0,849 , sehingga skala ini dianggap andal sebagai alat pengambil data pada penelitian ini. Sementara itu strategi coping diukur menggunakan skala strategi coping yang terdiri dari dua skala, yaitu skala problem focused coping (PFC) dan skala emotion focused coping (EFC). Skala PFC tersusun atas 5 aspek, yaitu perencanaan, strategi coping aktif, pengurangan aktivitas persaingan, mencari dukungan sosial instrumental dan pengendalian. Semakin tinggi skor yang diperoleh subjek, menunjukkan bahwa kecenderungan subjek untuk menampilkan PFC semakin tinggi, dan sebaliknya semakin rendah skor yang diperoleh menunjukkan semakin rendah pula kecenderungan penggunaan PFC. Skala EFC tersusun atas 8 aspek, yaitu pelepasan emosi, reinterpretasi positif, penerimaan, pelarian, pelarian mental, penyangkalan, mencari dukungan sosial emosional dan kembali ke ajaran agama. Semakin tinggi skor yang diperoleh subjek, menunjukkan bahwa kecenderungan subjek untuk menampilkan EFC semakin tinggi, dan sebaliknya semakin rendah skor yang diperoleh menunjukkan semakin rendah pula kecenderungan penggunaan EFC. Adapun reliabilitas dari skala dukungan sosial ini adalah 0,849 , sehingga skala ini dianggap andal sebagai alat pengambil data pada penelitian ini. Oleh karena subjek penelitian ini adalah lansia, maka pengisian skala dilakukan secara individual dengan didampingi oleh asisten peneliti. 
Data yang terkumpul dalam penelitian ini selanjutnya dianalisis dengan menggunakan analisis regresi. Analisis regresi digunakan untuk mengetahui hubungan dan menguji taraf signifikansi antara prediktor (dukungan sosial) dengan kriterium, yaitu PFC dan EFC. Data yang terkumpul dalam penelitian ini juga dianalisis secara deskriptif.

\section{HASIL DAN PEMBAHASAN}

Deskripsi data penelitian dilakukan untuk memberikan gambaran secara umum bagaimana kondisi subjek penelitian pada variabel yang diteliti. Untuk itu penulis mengolah data penelitian dengan menggunakan statistik deskriptif pada program SPSS versi 16.0. Secara rinci, deskripsi dan kategorisasi data penelitian selengkapnya tampak pada Tabel 1 .

Problem focused coping subjek memiliki rerata empiris sedikit di atas rerata hipotetik (Tabel 1). Hal ini menunjukkan bahwa secara rata-rata subjek menggunakan problem focused coping (PFC) dan dalam frekuensi yang sedang dalam menghadapi masalah. Jika dilihat pada jenis strategi coping yang digunakan, dapat terlihat kalau mencari dukungan sosia instrumental merupakan jenis coping yang paling sedikit digunakan diantara 5 jenis PFC. Sementara itu pada EFC, subjek memiliki rerata empiris sedikit di bawah rerata hipotetik, sehingga dapat diartikan bahwa subjek memiliki frekuensi penggunaan EFC yang sedang. Reinterpretasi positif dan kembali ke ajaran agama merupakan jenis coping yang sering digunakan. Jenis coping yang lain seperti penolakan, pelarian secara mental, tindakan pelarian, mencari dukungan sosial emosional maupun pelepasan emosi termasuk jarang digunakan oleh para lansia. Pada dukungan sosial, tampak bahwa para lansia mempersepsikan dukungan sosial yang cukup tinggi, baik secara keseluruhan maupun untuk sumber-sumber dukungan. Hal ini dapat diketahui dari rerata empiris yang jauh di atas rerata hipotetik.
Tabel 1. Deskripsi Skor Strategi Coping dan Dukungan Sosial

\begin{tabular}{|c|c|c|c|c|}
\hline \multirow{2}{*}{ Skala/Aspek } & \multicolumn{2}{|c|}{ Rerata } & \multirow{2}{*}{ SD } & \multirow{2}{*}{ Makna } \\
\hline & Hipotetik & Empiris & & \\
\hline Problem focused coping & 20 & 24.90 & 6.656 & Sedang \\
\hline - $\quad$ Perencanaan & 4 & 5.20 & 1.883 & Sedang \\
\hline $\begin{array}{l}\text { Menghadapi masalah } \\
\text { secara aktif }\end{array}$ & 4 & 6.07 & 1.530 & Tinggi \\
\hline - $\quad$ Pengendalian & 4 & 5.30 & 2.070 & Tinggi \\
\hline $\begin{array}{ll}\text { - } & \text { Mencari duksos } \\
\text { instrumental }\end{array}$ & 4 & 3.27 & 2.532 & Sedang \\
\hline $\begin{array}{ll} & \begin{array}{l}\text { Mengurangi aktifitas } \\
\text { persaingan }\end{array} \\
\end{array}$ & 4 & 5.07 & 1.680 & Sedang \\
\hline Emotion focused coping & 32 & 31.30 & 5.766 & Sedang \\
\hline - $\quad$ Reinterpretasi positif & 4 & 6.17 & 1.020 & Tinggi \\
\hline Penerimaan & 4 & 3.20 & 1.769 & Sedang \\
\hline Penolakan & 4 & 2.87 & 1.383 & Sedang \\
\hline Kembali ke ajaran agama & 4 & 7.60 & 1.102 & Tinggi \\
\hline Pelarian secara mental & 4 & 2.97 & 1.450 & Sedang \\
\hline - $\quad$ Tindakan pelarian & 4 & 2.70 & 1.393 & Sedang \\
\hline $\begin{array}{l}\text { - Mencari dukungan sosial } \\
\text { emosional }\end{array}$ & 4 & 2.87 & 1.655 & Sedang \\
\hline - $\quad$ Pelepasan emosi & 4 & 2.63 & 1.847 & Rendah \\
\hline Dukungan sosial & 24 & 38.27 & 5.112 & Tinggi \\
\hline $\begin{array}{l}\text { - } \begin{array}{l}\text { Dukungan significant } \\
\text { other }\end{array} \\
\end{array}$ & 8 & 14.43 & 2.417 & Tinggi \\
\hline - $\quad$ Dukungan keluarga & 8 & 15.17 & 1.895 & Tinggi \\
\hline - $\quad$ Dukungan teman & 8 & 9.70 & 3.303 & Sedang \\
\hline
\end{tabular}

Adapun secara rinci kategorisasi strategi coping subjek dapat dilihat pada Tabel 2 dan Tabel 3. 
Tabel 2. Kategorisasi Skor Problem Focused Coping

\begin{tabular}{cccc}
\hline Kategori & Interval & $\begin{array}{c}\text { Jumlah } \\
\text { (orang) }\end{array}$ & $\begin{array}{c}\text { Persentase } \\
\text { (\%) }\end{array}$ \\
\hline Tinggi & $28-40$ & 10 & 33,3 \\
\hline Sedang & $14-27$ & 20 & 66,7 \\
\hline Rendah & $0-13$ & 0 & 0 \\
\hline Jumlah & & 30 & 100 \\
\hline
\end{tabular}

Tabel 2 menunjukkan bahwa sebagian besar subjek (66,7\%) menggunakan problem focused coping dengan taraf sedang, sementara itu 33,3\% berada dalam kategori tinggi.

\section{Tabel 3. Kategorisasi Skor Emotion Focused Coping}

\begin{tabular}{cccc}
\hline Kategori & Interval & $\begin{array}{c}\text { Jumlah } \\
\text { (orang) }\end{array}$ & $\begin{array}{c}\text { Persentase } \\
(\mathbf{\%})\end{array}$ \\
\hline Tinggi & $43-64$ & 1 & $3,3 \%$ \\
\hline Sedang & $22-42$ & 28 & $93,3 \%$ \\
\hline Rendah & $0-21$ & 1 & $3,3 \%$ \\
\hline Jumlah & & 30 & 100 \\
\hline
\end{tabular}

Tabel 3 menunjukkan bahwa sebagian besar (28 orang atau 93,3\%) subjek menggunakan emotion focused coping sebagai cara menghadapi masalahnya dalam taraf sedang. Selanjutnya kategorisasi skor dukungan sosial dapat dilihat pada Tabel 4.Tabel 4 menunjukkan bahwa sebagian besar subjek (25 orang atau $83,3 \%$ ) mempersepsikan adanya dukungan sosial yang cukup tinggi pada dirinya ketika menghadapi masalah.
Tabel 4. Kategorisasi Skor Dukungan Sosial

\begin{tabular}{cccc}
\hline Kategori & Interval & $\begin{array}{c}\text { Jumlah } \\
\text { (orang) }\end{array}$ & $\begin{array}{c}\text { Persentase } \\
(\%)\end{array}$ \\
\hline Tinggi & $33-48$ & 25 & 83,3 \\
\hline Sedang & $17-48$ & 5 & 16,7 \\
\hline Rendah & $0-16$ & 0 & 0 \\
\hline Jumlah & & 30 & 100 \\
\hline
\end{tabular}

Hasil analisis regresi khususnya dari matriks interkorelasi di antara dukungan sosial dengan PFC dan EFC tampak dalam Tabel 5. Pada tabel 5 terlihat bahwa dukungan sosial memiliki korelasi positif yang cukup signifikan dengan PFC ( $r=0,628$, dengan $p<0,01$ ). Hal ini berarti semakin besar dukungan sosial diterima oleh para lansia, maka akan semakin tinggi frekuensi penggunaan problem focused coping oleh para lansia untuk menghadapi masalahnya. Pada masing-masing sumber dukungan, hanya dukungan significant others dan dukungan teman yang memiliki hubungan signifikan dengan $\mathrm{PFC}$, masing berturut-turut memiliki $r=0,373$ dengan $p<0,05$ dan $r=0,422$ dengan $p<0,05$. Sementara itu korelasi negatif ditemukan antara dukungan sosial dengan EFC $(-0,460$, dengan $p<0,05)$. Hal ini menunjukkan bahwa semakin besar dukungan sosial diterima oleh lansia, maka akan semakin rendah penggunaan emotion focused coping. Pada EFC ini, hanya dukungan dari significant others yang memiliki hubungan negatif yang signifikan dengan EFC, yang ditunjukkan dengan $r=-0,400$ dengan $p<0,05$. 
Tabel 5. Matriks Interkorelasi Antara Dukungan Sosial dengan PFC dan EFC

\begin{tabular}{|c|c|c|c|c|c|c|c|}
\hline & & $\begin{array}{l}\text { significant } \\
\text { other }\end{array}$ & $\begin{array}{l}\text { dukungan } \\
\text { keluarga }\end{array}$ & $\begin{array}{l}\text { dukungan } \\
\text { teman }\end{array}$ & $\begin{array}{l}\text { dukungan } \\
\text { sosial }\end{array}$ & $\begin{array}{l}\text { problem } \\
\text { focused } \\
\text { coping }\end{array}$ & $\begin{array}{l}\text { emotion } \\
\text { focused } \\
\text { coping }\end{array}$ \\
\hline \multirow[t]{2}{*}{$\begin{array}{l}\text { significant } \\
\text { other }\end{array}$} & $\begin{array}{l}\text { Pearson } \\
\text { Correlation }\end{array}$ & 1 & $.613^{* *}$ & .263 & $.752^{* *}$ & $.373^{*}$ & $-.400^{*}$ \\
\hline & Sig. (2-tailed) & & .000 & .160 & .000 & . .043 & .028 \\
\hline \multirow[t]{2}{*}{$\begin{array}{l}\text { dukungan } \\
\text { keluarga }\end{array}$} & $\begin{array}{l}\text { Pearson } \\
\text { Correlation }\end{array}$ & $.613^{* *}$ & 1 & .073 & $.691^{* *}$ & .226 & -.307 \\
\hline & Sig. (2-tailed) & . .000 & & .703 & .000 & .229 & . .098 \\
\hline \multirow[t]{2}{*}{$\begin{array}{l}\text { dukungan } \\
\text { teman }\end{array}$} & $\begin{array}{l}\text { Pearson } \\
\text { Correlation }\end{array}$ & .263 & . .073 & 1 & $.632^{* *}$ & $.422^{*}$ & -.188 \\
\hline & Sig. (2-tailed) & .160 & .703 & & .000 & .020 & .320 \\
\hline \multirow[t]{2}{*}{$\begin{array}{l}\text { dukungan } \\
\text { sosial }\end{array}$} & $\begin{array}{l}\text { Pearson } \\
\text { Correlation }\end{array}$ & $.752^{* *}$ & $.691^{* *}$ & $.632^{* *}$ & 1 & $.628^{* *}$ & $-.460^{*}$ \\
\hline & Sig. (2-tailed) & .000 & .000 & .000 & & .000 & .011 \\
\hline \multirow{2}{*}{$\begin{array}{l}\text { problem } \\
\text { focused } \\
\text { coping }\end{array}$} & $\begin{array}{l}\text { Pearson } \\
\text { Correlation }\end{array}$ & $.373^{*}$ & .226 & $.422^{*}$ & $.628^{* *}$ & 1 & $-.511^{* *}$ \\
\hline & Sig. (2-tailed) & . 043 & .229 & .020 & .000 & & .004 \\
\hline \multirow{2}{*}{$\begin{array}{l}\text { emotion } \\
\text { focused } \\
\text { coping }\end{array}$} & $\begin{array}{l}\text { Pearson } \\
\text { Correlation }\end{array}$ & $-.400^{*}$ & -.307 & -.188 & $-.460^{*}$ & $-.511^{* *}$ & 1 \\
\hline & Sig. (2-tailed) & . 028 & .098 & .320 & .011 & .004 & \\
\hline
\end{tabular}

*. Correlation is significant at the 0.05 level (2-tailed).

Adapun rangkuman hasil analisis regresi linear dalam menunjukkan hasil seperti tampak Tabel 6 .

\section{Tabel 6. Rangkuman Hasil Analisis Regresi Linear} Dukungan Sosial dengan PFC

\begin{tabular}{lcccccc}
\hline Prediktor & $R$ & $R^{2}$ & $B$ & $\beta$ & $F$ & $p$ \\
\hline Dukungan sosial & 0,628 & 0,395 & 0,818 & 0,628 & 18,247 & 0,000 \\
\hline Dukungan teman & 0,422 & 0,178 & 0,940 & 0,422 & 6,055 & 0,020 \\
\hline
\end{tabular}

Tabel 6 menunjukkan bahwa dukungan sosial berpengaruh sangat signifikan pada penggunaan problem focused copingpara lansia, dengan sumbangan sebesar 39,5\%. Dengan demikian dapat dikatakan bahwa $39,5 \%$ penggunaan problem focused coping para lansia dapat dijelaskan dari persepsinya terhadap dukungan sosial yang diterimanya. Selanjutnya berdasar analisis regresi metode stepwise dengan mengikutkan prediktor dukungan significant others, dukungan keluarga, dan dukungan teman didapatkan hasil bahwa hanya dukungan teman yang memiliki sumbangan signifikan pada problem focused coping yang digunakan oleh para subjek, dengan sumbangan sebesar 17, $8 \%$.

Berdasarkan hasil di atas juga dapat dikatakan bahwa dukungan sosial yang diterima dapat memprediksi problem focused coping yang digunakan oleh para lansia untuk menghadapi masalah. Semakin tinggi dukungan sosial diterima, akan semakin tinggi penggunaan problem focused coping ketika menghadapi masalah. Oleh karena itu hipotesis pertama penelitian ini dapat diterima atau terbukti.

Sementara itu rangkuman hasil analisis regresi linear dalam program SPSS untuk EFC dapat dilihat pada Tabel 7.

Tabel 7. Rangkuman Hasil Analisis Regresi Linear dukungan Sosial dengan EFC

\begin{tabular}{lcccccc}
\hline Prediktor & $R$ & $R^{2}$ & $B$ & $\beta$ & $F$ & $p$ \\
\hline Dukungan sosial & 0,460 & 0,212 & $-0,519$ & $-0,460$ & 7,523 & 0,011 \\
\hline $\begin{array}{l}\text { Dukungan } \\
\text { significant }\end{array}$ & 0,400 & 0,160 & $-0,929$ & $-0,400$ & 5,343 & 0,028
\end{tabular}

significant oth

Tabel 7 menunjukkan bahwa dukungan sosial berhubungan secara signifikan denganpenggunaan emotion focused coping para lansia, dengan sumbangan sebesar 21,2\%. Dengan demikian dapat dikatakan bahwa $21,2 \%$ penggunaan emotion focused coping para lansia dapat dijelaskan dari persepsinya terhadap dukungan sosial yang diterimanya. Selanjutnya berdasar analisis 
regresi metode stepwise dengan mengikutkan prediktor dukungan significant others, dukungan keluarga, dan dukungan teman didapatkan hasil bahwa hanya dukungan significant other yang memiliki sumbangan signifikan pada emotion focused coping yang digunakan oleh para subjek, dengan sumbangan sebesar 16 $\%$.

Berdasarkan hasil di atas juga dapat dikatakan bahwa dukungan sosial yang diterima dapat memprediksi emotion focused coping yang digunakan oleh para lansia untuk menghadapi masalah. Oleh karena arah hubungan negative, maka semakin tinggi dukungan sosial diterima, akan semakin rendah penggunaan emotion focused coping ketika menghadapi masalah. Oleh karena itu hipotesis kedua penelitian ini dapat diterima atau terbukti.

Berdasarkan uji hipotesis pertama dan kedua, ditemukan adanya pola penggunaan strategi coping pada para lansia Penggunaan problem focused coping dapat diprediksikan dari dukungan sosial secara umum dan dukungan teman secara khusus, sementara penggunaan emotion focused coping dapat diprediksikan dari dukungan sosial secara umum dan dukungan significant other secara khusus. Pola tersebut dapat dilihat dalam Tabel 8

Tabel 8. Pola Penggunaan Strategi Coping

\begin{tabular}{lcc}
\multicolumn{1}{c}{ Prediktor } & PFC & EFC \\
\hline Dukungan Sosial & Tinggi & Rendah \\
\hline Dukungan Teman & Tinggi & - \\
\hline Dukungan Keluarga & - & - \\
\hline Dukungan Significant other & - & Rendah \\
\hline
\end{tabular}

Hipotesis pertama penelitian ini, yang menyatakan ada hubungan positif antara dukungan sosial dengan problem focused coping telah terbukti. Adanya dukungan sosial yang tingg berhubungan dengan meningkatnya penggunaan problem focused coping atau strategi menghadapi masalah yang berorientasi pada masalah. Hal ini sesuai dengan apa yang ditemukan dalam penelitian Fiksenbaum, dkk (2006) bahwa meningkatnya dukungan sosial yang diterima oleh para lansia berhubungan dengan semakin seringnya coping proaktif yang dilakukan ketika menghadapi masalah. Jika dicermati dalam hasil penelitian ini (Tabel 1), coping aktif merupakan jenis PFC yang paling sering digunakan oleh para subjek di antara ke-4 jenis PFC lainnya. Coping aktif merupakan cara menghadapi masalah secara aktif, yaitu proses menggunakan langkah-langkah aktif untuk mencoba menghilangkan stressor atau memperbaiki akibatnya. Strategi ini meliputi memulai tindakan langsung, meningkatkan usaha, dan menghadapi masalah dengan cara-cara yang bijaksana. Fiksenbaum, dkk (2006) mencatat bahwa para lansia yang menggunakan coping aktif akan lebih mandiri, lebih bisa melakukan aktivitas sehari-hari seperti mencuci, memakai baju, serta berbelanja. Para lansia dengan coping aktif juga memiliki kemungkinan lebih kecil untuk mengalami stress sehari-hari seperti memiliki rasa khawatir akan kesehatan dan kesejahteraan psikologis. Hal ini juga dibuktikan dengan rendahnya angka masalah-masalah fisik dan psikologis pada para subjek.

Penggunaan PFC, khususnya coping aktif pada para lansia tersebut sebagaimana hasil pengujian hipotesis pertama di dalam penelitian ini didukung oleh tingginya dukungan sosial yang diterima oleh para lansia. Sebanyak 25 orang atau 83,3\% subjek penelitian ini mempersepsikan adanya dukungan sosial yang cukup tinggi pada mereka. Hal ini sejalan dengan pernyataan Watson (1984) yang menyatakan bahwa dukungan sosial merupakan sumber pengatasan yang mempengaruhi sejak proses penilaian terhadap ancaman sampai pada usaha mengatasi masalah (Watson, 1984).

Satu hal menarik dari penelitian ini adalah adanya temuan bahwa sumber dukungan yang secara signifikan memiliki 
sumbangan pada peningkatan PFC adalah dukungan teman, sementara sumbangan dukungan significant others dan dukungan keluarga kurang signifikan. Meskipun jika dilihat dari kuantitas dukungan teman ini lebih rendah dari dukungan keluarga dan dukungan significant others, tampaknya dukungan teman ini lebih bermakna bagi para lansia terutama berkaitan dengan penggunaan PFC. Hal ini kemungkinan disebabkan oleh rasa senasib di antara para lansia membuat para lansia merasa bahwa teman adalah orang yang dapat memahami masalah. Pemahaman yang mendalam terhadap masalah yang dihadapi lansia ini dapat muncul dari teman sebaya, dalam hal ini sesama lansia. Selain itu lingkungan sosial para lansia yang menjadi subjek penelitian ini kemungkinan juga memiliki peran penting dalam mempengaruhi hubungan antara dukungan sosial teman dengan PFC. Secara sosial, para lansia di dusun Ketonggo Wonokromo Pleret Bantul memiliki jalinan hubungan yang cukup erat melalui adanya kegiatankegiatan bersama para lansia seperti posyandu lansia serta pengajian, maupun kegiatan harian yang memungkinkan mereka bisa saling bertemu satu sama lain. Hasil penelitian ini sejalan dengan penelitian Cantor (1979) yang menemukan bahwa teman dan tetangga merupakan sumber dukungan yang penting bagi para lansia. Penelitian Schonfeld, dkk (1985) memperkuat hasil penelitian ini, bahwa teman merupakan salah satu prediktor yang potensial selain usia dan depresi terhadap kebutuhan akan treatment kesehatan mental. Hasil yang hampir sama juga ditemukan pada penelitian Thanakwang dan Soonthorndhada (2011), bahwa teman memiliki pengaruh langsung maupun tidak langsung pada perilaku peningkatan kesehatan para lansia sementara keluarga hanya memiliki pengaruh tidak langsung melalui dukungan sosial.

Hipotesis kedua penelitian ini, yaitu ada hubungan negatif antara dukungan sosial yang diterima dan emotion focused coping para lansia juga telah terbukti. Artinya semakin tinggi dukungan sosial diterima oleh para lansia, maka akan semakin rendah atau jarang para lansia menggunakan EFC dalam menghadapi masalanya. Sebesar 21,2 \% EFC dapat dijelaskan dari dukungan sosial. Jika dilihat pada deskripsi data, terlihat bahwa secara umum penggunaan EFC pada subjek penelitian ini berada pada kategori sedang, dengan mean empiris di bawah mean hipotetik. Hal ini menjadi dapat difahami karena besarnya dukungan sosial yang diterima oleh para lansia.

Penelitian ini menemukan adanya jenis EFC yang sering digunakan oleh para lansia, yaitu reinterpretasi positif serta kembali ke ajaran agama. Dalam bahasa keseharian, reinterpretasi positif dikenali dengan mengambil hikmah dari setiap masalah yang dihadapi. Kembali ke ajaran agama artinya mengembalikan setiap masalah pada ajaran agama, sehingga perlu dihadapi dengan memperbanyak beribadah dan berdoa. Kedua jenis coping ini berkaitan dengan usia para subjek yang tergolong lansia, yang mana ada kecenderungan pada para lansia untuk lebih mendekatkan diri pada Tuhan dalam perilaku sehari-hari. Kebermaknaan merupakan cara untuk dapat hidup secara berkualitas, dan hal ini dapat dibangun melalui pikiran yang positif serta hubungan yang dekat dengan kebenaran Tuhan. Cara ini diyakini membuat kehidupan mental spiritual para lansia menjadi lebih baik, sebagaimana hasil penelitian Pargament, dkk (2004) yang menemukan bahwa coping religius dapat memprediksi adanya kemajuan-kemajuan dalam kesehatan, perubahan mental serta kehidupan spiritual. Hal tersebut juga sejalan dengan penelitian Benjamins (2004), yang menemukan bahwa kehadiran dalam kegiatan-kegiatan religius dapat mengurangi menurunnya kemampuan fungsional pada lansia.

\section{SIMPULAN}

1. Ada hubungan positif yang signifikan antara dukungan sosial dengan problem focused coping PFC ( $F=18,247, p<0,01)$, dengan sumbangan sebesar 39,5\%. Dengan demikian semakin 
tinggi dukungan sosial, semakin tinggi para lansia dalam menggunakan problem focused coping.

2. Ada hubungan negatif yang signifikan antara dukungan sosia dengan emotion focused coping $F=7,523, p<0,05$ ), dengan sumbangan sebesar $21,2 \%$. Semakin tinggi dukungan sosial, akan semakin rendah penggunaan emotion focused coping.

3. Sumber dukungan sosial yang paling signifikan dalam memprediksi problem focused coping adalah dukungan teman, $(\mathrm{F}=6,055, \mathrm{p}<0,05)$, dengan sumbangan sebesar $17,8 \%$. Sementara sumber dukungan sosial yang paling signifikan dalam memprediksi emotion focused coping adalah dukungan dari significant other $(F=5,343, p<0,05)$, dengan sumbangan sebesar $16 \%$

4. Subjek menggunakan problem focused coping maupun emotion focused coping dalam kategori sedang. Jenis problem focused coping yang paling sering digunakan adalah coping aktif, sedangkan jenis emotion focused coping yang masuk dalam kategori sering digunakan adalah reinterpretasi positif dan kembali ke ajaran agama.

5. Sebagian besar subjek (25 orang atau 83,3\%) subjek mempersepsikan adanya dukungan sosial yang cukup tinggi pada dirinya, khususnya pada dukungan keluarga dan dukungan significant other.

6. Pola penggunaan problem focused coping dapat diprediksikan dari dukungan sosial secara umum dan dukungan teman secara khusus, sementara penggunaan emotion focused coping dapat diprediksikan dari dukungan sosial secara umum dan dukungan significant other secara khusus.

Berdasarkan kesimpulan penelitian tersebut, maka implikasi dari penelitian ini adalah:

1. Penguatan jaringan sosial antar lansia melalui pertemuanpertemuan lansia.

2. Peningkatan dukungan sosial bagi para lansia sebagai salah satu sumber strategi coping para lansia dalam menghadapi masalahnya.

\section{DAFTAR PUSTAKA}

Benjamins, M.R. 2004. Religion and Functional Health Among the Elderly : Is There a Relationship and Is It Constant?, Journal of Aging Health, vol 16 (3), 355-374

Bisconti, T. L., \& Bergeman, C. S. 1999.Perceived social control as a mediator of the relationships among social support, psychological well-being, and perceived health. Gerontologist, 39, 94-103

Cantor, M.H. 1979. Neighbors and Friends. Research on Aging, Vol 1 (4), 434-463

Fiksenbaum, L.M., Greenglass, E.R., \& Eaton, J. 2006. Perceived Social Support, Hassles, and Coping Among the Elderly. Journal of Applied Gerontology, 25 (1), 17-31

Folkman, S., Lazarus, R.S., Schetter, C.D., DeLongis, A., \& Gruen, R.J. 1986. Dynamics of stressful encounter: Cognitive appraisal, coping, and encounter outcomes. Journal of Personality and Social Psychology.50, 992 1003

Gottlieb, B.H. 1983. Social Support Strategies Guidelines for Mental Health Practices. London: Sage Publications

Lengua, L.J., \& Stormshak, E.A. 2000. Gender, gerder roles, and personality: gender differences in the prediction of coping and psychological symptom. Sex Roles, 43, 787-821

Pargament, K.I., Koenig, H.G., Tarakeshwar, N., \& Hahn, J. 2004 Religious Coping Methods as Predictors of Psychological, Physical and Spiritual Outcomes among Medically Ill Elderly Patients: A Two-year Longitudinal Study. Journal of Health Psychology, 9 (6), 713-730 
Park, C.L., Folkman, S., \& Bostrom, A. 2001. Appraisal of controllability and coping in caregivers and HIV + men: Testing the goodness-of-fit hypothesis. Journal of Consulting and Clinical psychology. 69, 481-488

Sarafino, E.P. 1990. Health psychology: Biopsychosocial interaction. New York: John Wiley \& Sons

Schultz, R.,\&Heckhausen, J. 1996. A life span model of successful aging. American Psychologist, 51, 702-714.

Stanton, A.L., Danoff-Burg, S., Cameron, C.L., \& Ellis, A.P. 1994 Coping through emotional approach: Problems of conceptualization and confounding.Journal of Personality and Social psychology. 66, 350-362

Taylor, S.E. 1995. Health psychology. New York: McGraw-Hill, Inc.

Thanakwang, K., \& Soonthorndhada, K. 2011. Mechanisms by which social support networks influence healthy aging among Thai community- dwelling elderly. Journal of Aging and Health, $X X(X), 1-27$

Watson, D.L., Tregerthan, G.B.,\& Frank, J. 1984. Social psychology: Science and application. Illinois: Scott, Foresman, and Company.
PERAN GENDER SUAMI ISTRI

DALAM KELUARGA DAN KASUS CERAI GUGAT

\section{Oleh:}

\section{Vita Fitria dan Sun Choirol Ummah}

Universitas Negeri Yogyakarta

\section{Abstrak}

Penelitian deskriptif kualitatif ini bertujuan mengungkap jenis peran gender yang dilakukan suami istri dalam keluarga, mengungkap kasus cerai gugat yang sering terjadi di Kabupaten Bantul Yogyakarta tahun 2008-2010, dan mengungkap keterkaitan antara peran gender suami istri dalam keluarga dengan cerai gugat yang dilakukan oleh istri di Kabupaten Bantul Yogyakarta tahun 2008-2010. Data tentang peran gender yang dikumpulkan melalui purposive sampling ini melibatkan empat orang istri yang mengalami perceraian di Kabupaten Bantul Yogyakarta Pengumpulan data penelitian dilakukan dengan menggunakan teknik kuesioner, wawancara mendalam, observasi, dan dokumentasi. Pemeriksaan keabsahan data digunakan teknik cross check, sedangkan analisis data digunakan teknik analisis induktif. Hasil penelitian menunjukkan beberapa simpulan, yakni: 1) peran gender dalam keluarg di Kabupaten Bantul Yogyakarta masih didominasi oleh pengaruh kultur budaya masyarakat Jawa yang menempatkan laki-laki sebagai pencar nafkah dan perempuan sebagai pengemban tugas domestik, 2) kasus cera gugat yang terjadi di Kabupaten Bantul sering dipicu oleh faktor ekonomi, dan 3) ketiadaan pembagian peran yang fleksibel antara laki-laki dan perempuan sangat rentan memicu terjadinya disfungsi peran laki-laki perenpuan sangat rentan memicu terjadinya disfungsi peran laki-laki

Kata kunci: peran gender, pencari nafkah, dan cerai gugat

\section{PENDAHULUAN}

Wacana tentang peran gender dalam keluarga yang pada dasa warsa terakhir ini intensif disuarakan para feminis dan aktivis gender Yogyakarta, umumnya belum dipahami secara proporsional oleh masyarakat Yogyakarta, utamanya di Kabupaten Bantul. Pada kenyataannya, Kabupaten Bantul yang 